\title{
Antinociceptive and anti-inflammatory effects of the essential oil of Eugenia candolleana DC., Myrtaceae, on mice
}

\author{
Adriana G. Guimarães, ${ }^{1}$ Mônica S. Melo, ${ }^{1}$ Rangel R. Bonfim, ${ }^{1}$ Luiz O. Passos, ${ }^{2}$ \\ Samísia M.F. Machado, ${ }^{2}$ Adauto de S. Ribeiro, ${ }^{3}$ Marcos Sobral, ${ }^{4}$ Sara M. Thomazzi, ${ }^{1}$ \\ Lucindo J. Quintans-Júnior ${ }^{*}, 1$
}

\begin{abstract}
'Departamento de Fisiologia, Universidade Federal de Sergipe, Campus Universitário "Prof. Aloísio de Campos", Av. Marechal Rondom s/n, 49100-000 São Cristóvão-SE, Brazil

${ }^{2}$ Departamento de Química, Universidade Federal de Sergipe, Campus Universitário "Prof. Aloísio de Campos", Av. Marechal Rondom s/n, 49100-000 São Cristóvão-SE, Brazil

${ }^{3}$ Departamento de Biologia, Universidade Federal de Sergipe, Campus Universitário "Prof. Aloísio de Campos", Av. Marechal Rondom s/n, 49100-000 São Cristóvão-SE, Brazil

${ }^{4}$ Instituto de Ciências Biológicas, Universidade Federal de Minas Gerais, Av. Antônio Carlos, 6627, Pampulha, 31270-901 Belo Horizonte-MG, Brazil
\end{abstract}

\begin{abstract}
RESUMO: "Efeito antinociceptivo e antiinflamatório do óleo essencial de Eugenia candolleana DC. (Myrtaceae) em roedores". Eugenia candolleana DC. (Myrtaceae), conhecida popularmente como "murta" ou "murtinha", é uma espécie vegetal sem estudos químicos e farmacológicos descritos na literatura, distribuída no Nordeste brasileiro, principalmente, na Zona da Mata. Na medicina popular do Estado de Sergipe é utilizada no tratamento de distúrbios febris e da dor. O presente estudo buscou avaliar as possíveis atividades antinociceptiva e antiinflamatória do óleo essencial extraído das folhas de E. candolleana DC (OEEc) em roedores. A administração intraperitoneal (i.p.) do $\operatorname{OEEc}(25,50$ e $100 \mathrm{mg} / \mathrm{kg})$ reduziu significativamente o número de contorções no teste das contorções abdominais e a duração da lambida da pata na segunda fase do teste da formalina $(p<0,001)$. Entretanto, a administração do OEEc não alterou o tempo de reação no teste da placa quente. No experimento de peritonite induzido por carragenina, o OEEc reduziu de forma significativa $(p<0,01)$ a migração de leucócitos para a cavidade peritoneal. Os resultados obtidos sugerem que o OEEc possui ação antinociceptiva, provavelmente mediado por mecanismos periféricos, e ação antiinflamatória.
\end{abstract}

Unitermos: Eugenia candolleana DC., antinociceptiva, antiinflamatória, contorções por ácido acético, formalina, peritonite aguda induzido por carragenina.

\begin{abstract}
Eugenia candolleana DC. (Myrtaceae), commonly known as "murta" or "murtinha", is a plant species without any chemical or pharmacological study described in the literature. It has been popularly used for the treatment of pain and fever. This report aimed to investigate the possible antinociceptive and anti-inflammatory effects of the essential oil extracted from fresh leaves of Eugenia candolleana DC. (EOEc) in rodents. Following intraperitoneal injection, EOEc $(25,50$ and $100 \mathrm{mg} / \mathrm{kg}$ ) reduced the number of writhes significantly in a writhing test and the number of paw licks during phase two of formalin test $(p<0.001)$. However, administration of EOEc did not alter the time of reaction in hot plate test. Furthermore, EOEc inhibited $(p<0.01)$ the carrageenaninduced leukocyte migration to the peritoneal cavity. These results indicate antinociceptive and anti-inflammatory properties of EOEc probably mediated via inhibition of prostaglandin synthesis or other peripherally pathway.
\end{abstract}

Keywords: Eugenia candolleana DC., antinociceptive activity, anti-inflammatory activity, acetic acid-induced writhing, formalin, carrageenan-induced pleurisy. 


\section{INTRODUCTION}

In Brazil, natural products such as plants constitute traditional sources of clinical treatment of diverse pathophysiological conditions; in some cases, they are the unique therapeutic approach that some groups or communities possess to cure themselves from health disturbs (Coelho-de-Souza et al., 2004; Barbosa-Filho et al., 2006)

The Myrtaceae consists of around one hundred twenty nine genera and four thousand six hundred twenty species (Mabberley, 1997). One important member of this family is Eugenia, which is one of the larger genera with around five hundred species (Mabberley, 1997). Several species of Eugenia have been reported for then uses in folk medicine. For example, in the state of Amazonas, at the north of the country, infusions of E. punicifolia, are largely employed, although empirically, to treat hyperglycaemic disturbs, such as diabetes mellitus. E. punicifolia, popularly known as "pedra-ume-cáa", is a tree widely distributed in Amazonas and it's mentioned popular application is related to the uses of fresh leaves in decoction or infusions (Grangeiro et al., 2006). According to Cole et al. (2007) the most abundant components of Eugenia species are monoterpenoids and sesquiterpenoids.

Eugenia candolleana DC. (Myrtaceae), popularly known as "murta" or "murtinha", a rare Eugenia of the Northwestern Brazilian rainforests, bearing a small, darkpurple ripening fruit with a mildly sweet and firm pulp. There are no pharmacological and chemical information about the plant species on literature. However, has been used in folk by practitioners the infusion of the fleshy leaves for the treatment of pain and fever (oral communication).

Therefore, the purpose of present study was to evaluate the effects of essential oil of $E$. candolleana DC. (EOEc) on the antinociceptive and anti-inflammatory activities using acetic acid-induced writhing, formalin, hot plate and peritonitis tests in mice.

\section{MATERIAL AND METHODS}

\section{Plant material and essential oil (EOEc) extraction}

Leaves of the Eugenia candolleana DC. (Myrtaceae) were collected in Serra da Guia, Poço

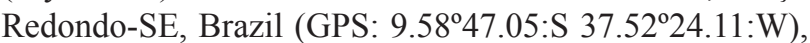
Brazil, and a voucher sample has been deposited in the Herbarium of the Department of Botanic from Universidade Federal de Minas Gerais (BHCB n ${ }^{\circ} 635$, Adauto Ribeiro). The essential oil was obtained by hydrodistillation in a Clevenger-type apparatus using $300 \mathrm{~g}$ of fresh leaves, during three hours after the boil. The oil obtained was dried over anhydrous sodium sulphate, producing yields of $1.09 \%(\mathrm{v} / \mathrm{w})$.

\section{Drugs}

Dexamethasone, morphine and polyoxyethylenesorbitan monolated (Tween 80 ) was purchased from Sigma (USA) and acetylsalicylic acid (ASA), was obtained from Roche (Brazil). All drugs and the essential oil were administered intraperitoneally (i.p.) in volumes of 0.1 $\mathrm{mL} / 10 \mathrm{~g}$ (mice).

\section{Animals}

Male Swiss mice (28-34 g), 2-3 months of age, were used throughout this study. The animals were randomly housed in appropriate cages at $25 \pm 2^{\circ} \mathrm{C}$ on a $12 \mathrm{~h}$ light/dark cycle (lights on 06:00-18:00 h) with free access to food $\left(\right.$ Purina $^{\circledR}$ ) and water. They were used in groups of six or ten animals each. All experiments were carried out between 09:00 $\mathrm{h}$ and 16:00 $\mathrm{h}$ in a quiet room. Experimental protocols and procedures were approved by the Animal Research Ethics Committee of the Federal University of Sergipe (CEPA/UFS Nº 08/08).

\section{Acetic acid-induced writhing}

This test was done using the method described by Koster et al. (1959) and Broadbear et al. (1994). Muscular contractions were induced by intraperitoneal injection (i.p.) of a $0.85 \%$ solution of acetic acid $(0.25 \mathrm{~mL} / \mathrm{animal})$. The number of muscular contractions was counted for $15 \mathrm{~min}$ after injection and the data represents the average of the total number of writhes observed. EOEc was administered in doses of 25,50 and $100 \mathrm{mg} / \mathrm{kg}$ (i.p., $\mathrm{n}=10$ per group). The reference drug, acetylsalicylic acid (aspirin), was solubilized in saline +1 drop of Tween- $800.2 \%$ (vehicle) and was administered intraperitoneally $(200 \mathrm{mg} / \mathrm{kg})$ to different groups of the mice $0.5 \mathrm{~h}$ before the acetic acid injection.

\section{Formalin test}

The observation chamber was a glass box of 30 $\mathrm{cm}$ diameter on an acrylic transparent plate floor. Beneath the floor, a mirror was mounted at a $90^{\circ}$ angle to allow clear observation of the paws of the animals. The animals were treated with the vehicle (saline +1 drop of Tween- 80 $0.2 \%), \operatorname{EOEc}(25,50$, and $100 \mathrm{mg} / \mathrm{kg}$, i.p.), or the reference drug (aspirin $200 \mathrm{mg} / \mathrm{kg}$, i.p.) $0.5 \mathrm{~h}$ before the formalin injection. Each mouse was placed in the chamber more than 5 min before treatment in order to allow acclimatization to the new environment. The formalin test was carried out as described by Hunskaar \& Hole (1987). Twenty microliters of a $2.5 \%$ formalin solution ( $0.92 \%$ formaldehyde) in a phosphate-buffer were injected into the dorsal surface of the left hind paw using a micro syringe with a 26-gauge needle. Each animal was then returned to the chamber and the amount of time that the animal spent licking the 
injected paw was considered to be indicative of pain. Two distinct phases of intensive licking activity were identified: an early acute phase and a late or tonic phase (0-5 and 15$30 \mathrm{~min}$ after formalin injection, respectively).

\section{Hot plate test}

The hot plate test described by Jacob et al. (1974) and by Jacob \& Ramabadran (1978) was used. Animals were placed on an aluminum plate that was adapted to a water bath at $50 \pm 0.5{ }^{\circ} \mathrm{C}$. The reaction time was noted by observing either the licking of the hind paws or the rotation movements at basal, $0.5,1.0,1.5$ and $2.0 \mathrm{~h}$ after i.p. administration of 25,50 and $100 \mathrm{mg} / \mathrm{kg}$ of EOEc or the vehicle (saline +1 drop of Tween-80 0.2\%) to different groups of ten mice. Morphine, $5 \mathrm{mg} / \mathrm{kg}$ (i.p.), was used as the reference drug.

\section{Leukocyte migration to the peritoneal cavity}

The leukocyte migration was induced by injection of carrageenan $(1 \%$, i.p., $0.25 \mathrm{~mL})$ into the peritoneal cavity of mice $1 \mathrm{~h}$ after administration of $\operatorname{EOEc}(25,50$ and $100 \mathrm{mg} / \mathrm{kg}$, i.p., $n=6)$, dexamethasone $(2 \mathrm{mg} / \mathrm{kg}$, s.c., $n=6$ ) or vehicle (saline +1 drop of Tween- $800.2 \%, n=6$ ) by modification of the technique previously described by Matos et al. (2003). The animals were anesthetized with sodium pentobarbital $(50 \mathrm{mg} / \mathrm{kg}$, i.p.) and were euthanized by cervical dislocation $4 \mathrm{~h}$ after carrageenan injection. Shortly after, saline containing EDTA $(1 \mathrm{mM}$, i.p., $3 \mathrm{~mL})$ was injected. Immediately a brief massage was done for further fluid collection, which was centrifuged $(5,000 \mathrm{rpm}$, $5 \mathrm{~min}$ ) at room temperature. The supernatant was disposed and $1 \mathrm{~mL}$ of PBS was introduced to the precipitate. An aliquot of $10 \mu \mathrm{L}$ from this suspension was dissolved in 200 $\mu \mathrm{L}$ of Turk solution and the total cells were counted in a Neubauer chamber, under optic microscopy. The results were expressed as the number of leukocyte $/ \mathrm{mL}$. The percentage of the leukocyte inhibition $=(1-T / C) \times 100$, where $T$ represents the treated groups leukocyte counts and $C$ represents the control group leukocyte counts.

\section{Statistical analysis}

The obtained data was evaluated by one-way analysis of variance (ANOVA) followed by Dunnett's or Fisher's test. In all cases differences were considered significant if $p<0.05$. The percent of inhibition by an antinociceptive agent was determined for the acetic acidinduced writhing and formalin tests using the following formula (Reanmongkol et al., 1994):

$$
\text { Inhibition } \%=\frac{100(\text { control }-\exp )}{\text { control }}
$$

\section{RESULTS}

Acetic acid-induced writhing

Table 1 shows that EOEc significantly $(p<$ $0.001)$ reduced, in a dose-dependent manner, the number of writhing movements induced by the i.p. administration of the acetic acid solution. As can be seen in Table 1, all doses produced a similar effect to aspirin $(200 \mathrm{mg} / \mathrm{kg})$.

Table 1. Effect of EOEc or aspirin on writhing induced by acetic acid.

\begin{tabular}{|c|c|c|c|}
\hline Trea & $\begin{array}{c}\text { Dose } \\
(\mathrm{mg} / \mathrm{kg})\end{array}$ & Number of writhings ${ }^{\mathrm{a}}$ & $\%$ Inhibition \\
\hline Vehicle & - & $13.4 \pm 4.8$ & - \\
\hline EOEc & 25 & $7.2 \pm 3.8^{\mathrm{b}}$ & $46.3^{d}$ \\
\hline $\mathrm{EOEc}$ & 50 & $3.9 \pm 2.7^{\mathrm{b}}$ & $70.9^{\mathrm{e}}$ \\
\hline $\mathrm{EOEc}$ & 100 & $1.4 \pm 0.7^{\mathrm{c}}$ & $89.6^{\mathrm{f}}$ \\
\hline Aspirin & 200 & $3.5 \pm 2.1^{\mathrm{b}}$ & $73.9^{d}$ \\
\hline \multicolumn{4}{|c|}{$\begin{array}{l}n=10 \text {; }^{\text {a }} \text { Values represent mean } \pm \text { S.E.M.; }{ }^{b} \mathrm{P}<0.05 \text { (one-way } \\
\text { ANOVA and Dunnett`s test), significantly different from control } \\
{ }^{c} \mathrm{P}<0.001 \text { (one-way ANOVA and Dunnett`s test), significantly } \\
\text { different from control; }{ }^{\mathrm{d}} \mathrm{P}<0.05 \text { (Fisher`s test), significantly } \\
\text { different from control.; }{ }^{\text {e }} \mathrm{P}<0.01 \text { (Fisher`s test), significantly } \\
\text { different from control.; }{ }^{\mathrm{f}} \mathrm{P}<0.001 \text { (Fisher`s test), significantly } \\
\text { different from control. }\end{array}$} \\
\hline
\end{tabular}

\section{Formalin test}

The results of this test are shown in Table 2. EOEc inhibited the two phases of the formalin response, in higher dose. In the first phase, EOEc $(100 \mathrm{mg} / \mathrm{kg})$ significantly reduced the licking time compared with the control group (Table 2). Intraperitoneal administration of EOEc, at all doses, significantly reduced $(p<0.001)$ pain in the second phase of the formalin test, as shown in Table 2. This decrease occurred in a dose-dependent manner.

Table 2. Effect of EOEc or aspirin on formalin-induced pain.

\begin{tabular}{|c|c|c|c|c|c|}
\hline \multirow{3}{*}{ Treatment } & \multirow{3}{*}{$\begin{array}{c}\text { Dose } \\
(\mathrm{mg} / \mathrm{kg})\end{array}$} & \multicolumn{4}{|c|}{ Number of licks (s) } \\
\hline & & \multicolumn{2}{|c|}{$0-5 \mathrm{~min}$} & \multicolumn{2}{|c|}{$15-30 \mathrm{~min}$} \\
\hline & & $\begin{array}{c}\text { Score of } \\
\text { paina }\end{array}$ & $\begin{array}{c}\% \\
\text { inhibition }\end{array}$ & $\begin{array}{c}\text { Score of } \\
\text { paina }\end{array}$ & $\begin{array}{c}\% \\
\text { inhibition }\end{array}$ \\
\hline Vehicle & - & $50.2 \pm 9.6$ & - & $37.8 \pm 11.5$ & - \\
\hline EOEc & 25 & $31.4 \pm 8.9$ & $37.5^{\mathrm{d}}$ & $5.2 \pm 3.9^{\mathrm{c}}$ & $86.2^{\mathrm{f}}$ \\
\hline EOEc & 50 & $34.5 \pm 7.8$ & $31.3^{\mathrm{d}}$ & $1.3 \pm 0.8^{\mathrm{c}}$ & $96.7^{f}$ \\
\hline EOEc & 100 & $22.3 \pm 9.1^{\mathrm{b}}$ & $55.6^{\mathrm{e}}$ & $4.6 \pm 3.2^{\mathrm{c}}$ & $87.8^{\mathrm{f}}$ \\
\hline Aspirin & 200 & $45.7 \pm 9.3$ & 9.0 & $6.3 \pm 5.1^{\mathrm{c}}$ & $83.3^{\mathrm{f}}$ \\
\hline
\end{tabular}

$n=10$; ${ }^{\text {a }}$ Values represent mean \pm S.E.M.; ${ }^{\mathrm{b}} \mathrm{P}<0.05$ (one-way ANOVA and Dunnett's test), significantly different from control; c $\mathrm{P}<0.001$ (one-way ANOVA and Dunnett's test), significantly different from control; ${ }^{\mathrm{d}} \mathrm{P}<0.05$ (Fisher`s test), significantly different from control; ${ }^{\mathrm{e}} \mathrm{P}<0.01$ (Fisher's test), significantly different from control; ${ }^{\mathrm{f}} \mathrm{P}<0.001$ (Fisher's test), significantly different from control. 


\section{Hot plate test}

Table 3 shows the results of the hot plate test. All doses of EOEc were ineffective in inhibiting the time of reaction to the thermal stimulus compared to control (vehicle). The reaction time parameter was only significantly increased $(p<0.01)$ where morphine administered (5 mg/kg, i.p.).

\section{Leukocyte migration to the peritoneal cavity}

Figure 1 shows the inhibitory effect of EOEc on carrageenan-induced response (58.5 and 52.6\% at 50 and $100 \mathrm{mg} / \mathrm{kg}$, respectively, $p<0.01)$. The results obtained with the control group support the effect of EOEc since the vehicle presented no activity, and the control drug dexamethasone inhibited $(50.4 \%, p<0.01)$ the carrageenan-induced leukocyte migration to the peritoneal cavity.

Table 3. Antinociceptive effect of EOEc on the hot plate test in mice.

\begin{tabular}{lcccccc}
\hline \multirow{2}{*}{ Treatment } & Dose $(\mathrm{mg} / \mathrm{kg})$ & \multicolumn{5}{c}{ Reaction time $(\mathrm{s})^{\mathrm{a}}$} \\
\cline { 3 - 7 } & & Basal & $0.5 \mathrm{~h}$ & $1 \mathrm{~h}$ & $1.5 \mathrm{~h}$ & $2 \mathrm{~h}$ \\
\hline Vehicle & - & $8.1 \pm 3.2$ & $7.1 \pm 3.1$ & $7.8 \pm 3.9$ & $7.7 \pm 3.1$ & $9.5 \pm 4.8$ \\
EOEc & 25 & $7.9 \pm 3.5$ & $11.7 \pm 3.8$ & $11.2 \pm 4.2$ & $10.4 \pm 3.9$ & $8.9 \pm 5.1$ \\
EOEc & 50 & $9.2 \pm 4.3$ & $12.8 \pm 4.3$ & $12.1 \pm 5.7$ & $9.8 \pm 4.6$ & $10.6 \pm 5.2$ \\
EOEc & 100 & $9.7 \pm 3.8$ & $9.8 \pm 4.7$ & $7.2 \pm 4.9$ & $10.2 \pm 5.8$ & $12.1 \pm 5.5$ \\
Morphine & 5 & $8.1 \pm 2.5$ & $27.2 \pm 4.9^{\mathrm{b}}$ & $26.5 \pm 3.8^{\mathrm{b}}$ & $28.2 \pm 5.1^{\mathrm{b}}$ & $29.1 \pm 4.7^{\mathrm{b}}$ \\
\hline
\end{tabular}

$\mathrm{n}=10 ;{ }^{\text {a }}$ Values represent mean \pm S.E.M.; ${ }^{\mathrm{b}} \mathrm{P}<0.01$ (one-way ANOVA and Dunnett's test), significantly different from control

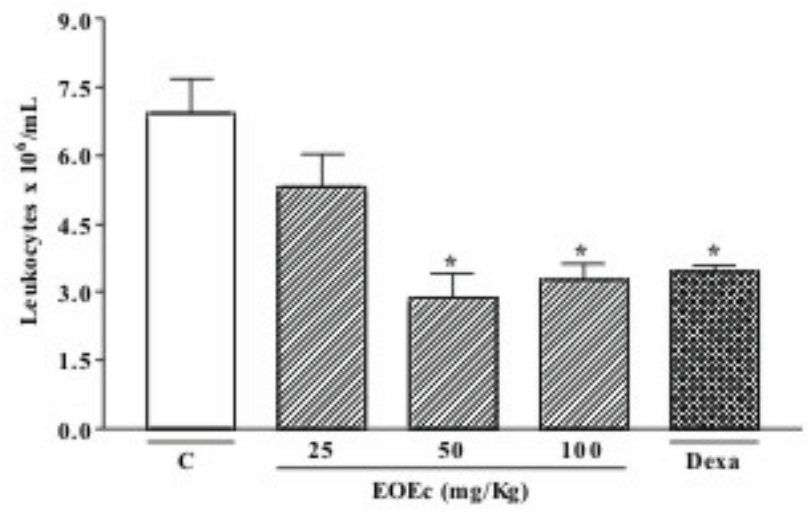

Figure 1. Effect of EOEc on leukocyte migration into the peritoneal cavity induced by carrageenan. Groups of mice were pre-treated with vehicle $(\mathrm{C}, 0.1 \mathrm{~mL} / 10 \mathrm{~g}$, i.p., open column), dexamethasone (Dexa, $2 \mathrm{mg} / \mathrm{kg}$, s.c., cross-hatched column), or EOEc at doses of 25,50 , and $100 \mathrm{mg} / \mathrm{kg}$ (i.p., right-hatched columns) $1 \mathrm{~h}$ before carrageenan $(1 \%, 0.25 \mathrm{~mL}$, i.p. $)$-induced peritonitis. Cell counts were performed at the time $4 \mathrm{~h}$ after the injection of carrageenan. Each value represents the mean \pm s.e.m. Asterisks denote statistical significance, ${ }^{*} p<0.01$ related to control group. ANOVA followed by Dunnett's test $(n=6)$.

\section{DISCUSSION}

There is no pharmacological and chemical studies about Eugenia candolleana DC. (Myrtaceae) described in literature. Therefore, the antinociceptive and antiinflammatory effects of essential oil of E. candolleana DC. (EOEc) were tested in three different models of analgesia (the acetic acid-induced writhing test, formalin-induced paw licking model and the hot plate test) and one model of inflammation (peritonitis) in rodents.
The inhibitory effect of EOEc in the writhing test is shown in Table 1. EOEc significantly inhibited the writhing in mice in a dose-dependent manner. Acetic acid-induced writhing is a standard, simple, and sensitive test for measuring analgesia induced by both opioids and peripherally acting analgesics (Hayes et al., 1987; Hunskaar \& Hole, 1987). Additionally, although this test is a nonspecific model (e.g. anticholinergic and antihistaminic and other agents show activity in this test) it is widely used for analgesic screening and involves local peritoneal receptors (cholinergic and histaminic receptor) (Alexandre-Moreira et al., 1999). These results support the hypothesis of EOEc participation in the inhibition of prostaglandin synthesis, as the nociceptive mechanism involves the process or release of arachidonic acid metabolites via cyclooxygenase (COX), prostaglandin biosynthesis (Bingham et al., 2006) or other peripherally pathway.

The formalin test has an advantage over other frequently used tests as it involves a biphasic response with an early and a late phase representing respectively neurogenic and inflammatory pain and agents can be screened for activity in these two phases models of pain (Hunskaar \& Hole, 1987). This is of interest considering that both phases are sensitive to centrally acting drugs, such as opioids (Shibata et al., 1989). However, the second phase is also sensitive to NSAIDs (non-steroidal, anti-inflammatory drugs) and corticosteroids (Hunskaar \& Hole, 1987). Table 2 shows that EOEc $(25,50$, and 100 $\mathrm{mg} / \mathrm{kg}$, i.p.) significantly inhibited $(p<0.001)$ the second phase.

Moreover, it was used the hot plate test to check for a possible central antinociceptive effect of the EOEc 
since this is considered a specific test for the study central pain. EOEc did not interfere with nociception in this test (Table 3).

The inflammation induced by carrageenan involves cell migration, plasma exsudation and production of mediators, such as nitric oxide, prostaglandin $\mathrm{E}_{2}$, interleukin (IL)-1 $\beta$, IL-6 and tumour necrosis factor (TNF)- $\alpha$ (Salvemini et al., 1996; Loram et al., 2007). These mediators are able to recruit leukocytes, such as neutrophils, in several experimental models. Figure 1 shows that EOEc inhibited leukocyte migration induced by carrageenan and a putative mechanism associated with this activity may be inhibition of the synthesis of many inflammatory mediators involved in the cell migration.

It can be concluded from the present study that the essential oil of $E$. candolleana DC (EOEc) possess antinociceptive and anti-inflammatory properties, which are probably mediated via inhibition of prostaglandin synthesis or other peripherally pathway. Further studies currently in progress will enable as to understand the precise action mechanisms.

\section{ACKNOWLEDGEMENTS}

The authors thank the Research Supporting Foundation of State of Sergipe (Fundação de Amparo à Pesquisa do Estado de Sergipe/FAPITEC-SE) and National Council of Technological and Scientific Development (Conselho Nacional de Desenvolvimento Científico e Tecnológico - CNPq) for the financial support.

\section{REFERENCES}

Alexandre-Moreira MS, Piuvezam MR, Araújo CC, Thomas G 1999. Studies on the anti-inflammatory and analgesic activity of Curatella americana L. J Ethnopharmacol 67: 171-177.

Barbosa-Filho JM, Medeiros KCP, Diniz MFFM, Batista LM, Athayde-Filho PF, Silva MS, da-Cunha EVL, Almeida JRGS, Quintans-Júnior LJ 2006. Natural products inhibitors of the enzyme acetylcholinesterase. Rev Bras Farmacogn 16: 258-285.

Bingham S, Beswick PJ, Blum DE, Gray NM, Chessell IP 2006. The role of the cylooxygenase pathway in nociception and pain. Semin Cell Dev Biol 17: 544-554.

Broadbear JH, Negus SS, Butelman ER, Costa BR, Woods JH 1994. Differential effects of systemically administered nor-binaltorphimine (nor-BNI) on $\kappa$-opioid agonists in the mouse writhing assay. Psychopharmacology 115: 311-319.

Coelho-de-Souza G, Haas APS, Von Poser GL, Schapoval EES, Elisabetsky E 2004. Ethnopharmacological studies of antimicrobial remedies in south of Brazil. $J$ Ethnopharmacol 90: 135-143.

Cole RA, Haber WA, Setzer WN 2007. Chemical composition of essential oils of seven species of Eugenia from Monteverde, Costa Rica. Biochem Syst Ecol 35: 877886.

Grangeiro MS, Calheiros-Lima AP, Martins MF, Arruda JF,
Garcez-do-Carmo L, Santos WC 2006. Pharmacological effects of Eugenia punicifolia (Myrtaceae) in cholinergic nicotinic neurotransmission. J Ethnopharmacol 108: 2630 .

Hayes AG, Sheehan MJ, Tyers TB 1987. Differential sensitivity of models of antinociception in the rat, mouse and guinea-pig to mu-and kappa-opioid receptor agonists. $\mathrm{Br}$ J Pharmacol 91: 823-832.

Hunskaar S, Hole K 1987. The formalin test in mice: dissociation between inflammatory and non-inflammatory pain. Pain 30: 103-104.

Jacob JJC, Tremblay EC, Coiomeel MC 1974. Facilitation the reactions nociceptives by naloxone in mice and rats. Psychopharmacology 37: 213-223.

Jacob JJC, Ramabadran K 1978. Enhancement of a nociceptive reaction by opiate antagonists in mice. $\mathrm{Br} J$ Pharmacol 64: 91-98.

Koster R, Anderson M, Beer EJ 1959. Acetic acid for analgesic screening. Fed Proc 18: 412-416.

Loram LC, Fuller A, Fick LG, Cartmell T, Poole S, Mitchell D 2007. Cytokine profiles during carrageenan-induced inflammatory hyperalgesia in rat muscle and hind paw. J Pain 8: 127-136.

Mabberley DJ 1997. The Plant-book. Cambridge: Cambridge University Press.

Matos LG, Santos LDAR, Vilela CF, Pontes IS, Tresvenzol LMF, Paula JR, Costa EA 2003. Atividades analgésica e/ou antiinflamatória da fração aquosa do extrato etanólico das folhas da Spiranthera odoratissima A. St. Hillaire (manacá). Rev Bras Farmacogn 13: 15-16.

Reanmongkol W, Matsumoto K, Watanabe H, Subhadhirasakul S, Sakai SI 1994. Antinociceptive and antipyretic effects of alkaloids extracted from the stem bark of Hunteria zeylanica. Biol Pharm Bull 17: 1345-1350.

Shibata M, Ohkubo T, Takahashi H, Inoki R 1989. Modified formalin test: characteristic biphasic pain response. Pain 38: 347-352.

Salvemini D, Wang ZQ, Wyatt PS, Bourdon DM, Marino MH, Manning PT, Currie MG 1996. Nitric oxide: a key mediator in the early and late phase of carrageenaninduced rat paw inflammation. Br J Pharmacol 118: 829838 . 